\title{
CYP2B6 wt Allele
}

National Cancer Institute

\section{Source}

National Cancer Institute. CYP2B6 wt Allele. NCI Thesaurus. Code C52356.

Human CYP2B6 wild-type allele is located in the vicinity of 19q13.2 and is approximately $27 \mathrm{~kb}$ in length. This allele, which encodes cytochrome P450 2B6 protein, is involved in the oxidation of fatty acids, steroids, drugs and xenobiotics. 